\title{
ASTHMA MIGHT PROTECT AGAINST MORTALITY IN CHILDREN HOSPITALIZED WITH COVID-19
}

Braian Sousa ${ }^{1}$, Paulo Mai $^{1}$, Sandra Vieira ${ }^{1}$, Antonio Pastorino ${ }^{1}$, and Alexandre Ferraro ${ }^{2}$

${ }^{1}$ Universidade de Sao Paulo Faculdade de Medicina

${ }^{2}$ Universidade de Sao Paulo

December 1, 2021

\section{ASTHMA MIGHT PROTECT AGAINST MORTALITY IN CHILDREN HOSPITALIZED WITH COVID-19}

Braian Lucas Aguiar Sousa, MD

University of São Paulo School of Medicine - Department of Pediatrics. Sao Paulo, Brazil.

Paulo Victor Ferreira Mai, MD

University of São Paulo School of Medicine - Department of Pediatrics. Sao Paulo, Brazil.

Sandra Elisabete Vieira, MD, PhD

University of São Paulo School of Medicine - Department of Pediatrics. Sao Paulo, Brazil.

Antonio Carlos Pastorino, MD, PhD

University of São Paulo School of Medicine - Department of Pediatrics. Sao Paulo, Brazil.

Alexandre Archanjo Ferraro, MD, PhD

University of São Paulo School of Medicine - Department of Pediatrics. Sao Paulo, Brazil.

Running title: Asthma might protect against COVID-19 mortality.

Corresponding Author:

Braian Lucas Aguiar Sousa, MD

Av Dr Eneas Carvalho de Aguiar, 647. São Paulo - Brazil

Braian.sousa@usp.br/braianlucas@gmail.com

Word count: 1196

Number of tables: 2

Number of figures: 0

ASTHMA MIGHT PROTECT AGAINST MORTALITY IN CHILDREN HOSPITALIZED WITH COVID-19

To the Editor,

The COVID-19 pandemic has been the greatest health challenge of the century, claiming the lives of over five million people so far. Fortunately, children and adolescents have been relatively spared, with most of the 
deaths being among the eldest and those with preexisting medical conditions. However, pediatric COVID19 morbidity and mortality are possible, especially among clinically and/or socioeconomically vulnerable patients. Multiple studies have reported the risk associated with specific previous comorbidities that might increase the odds of adverse outcomes. ${ }^{1}$ Asthma is one of the most common chronic diseases of childhood. The role played by the condition on the outcomes of pediatric COVID-19 patients is still up for discussion. To add to the debate, we have performed a large retrospective analysis of pediatric COVID-19 patients hospitalized in Brazil, up to September 2021.

We have extracted data from the SIVEP-Gripe database, a national surveillance databank that records data from all hospitalized patients with severe acute respiratory infections, including COVID-19. The notification is mandatory, and each observation contains over 160 fields with information including demographic characteristics (like age, sex, self or parent-reported race, municipality of residence), clinical presentation, self or parent-reported comorbidities, etiological investigation, and outcomes. We have included all patients with ages ranging from 5 to 20 years, hospitalized, with COVID-19 infection confirmed either by a positive PCR, positive antigen test, or positive IgM test. Patients without a defined final outcome (discharge or death) by September $6^{\text {th }}, 2021$ were excluded. After describing the sociodemographic characteristics and clinical outcomes of asthmatic and non-asthmatic patients, we studied the association of asthma with three possible outcomes: pediatric intensive care unit (PICU) admission, use of invasive ventilatory support (IVS), and in-hospital mortality. We used multilevel mixed-effects generalized linear models (GLM) to calculate de odds ratio (OR) between exposure and outcomes, assuming municipality and health unit of hospitalization as random effects.

The analysis included 9,807 patients, 858 (8.7\%) of whom had a self or parent-reported diagnosis of asthma. Table 1 compares the sociodemographic characteristics and outcomes of asthmatic and non-asthmatic patients. When compared to asthmatic patients, a higher proportion of non-asthmatic children lived in the northern half of the country and were female. They also had more comorbidities and were older. As for the outcomes, there was no difference among the groups in PICU admission and IVS. Ten percent of non-asthmatic children died, while for asthmatics this number was only $6.4 \%(\mathrm{p}=0.001)$.

Table 2 shows the risk of adverse outcomes for asthmatic patients taking non-asthmatic children as reference, and stratifying for age. For children from 5 to 10 years, asthma lowers the risk of death by $56 \%(95 \%$ CI 0.20-0.97) on the adjusted model. For all other outcomes and age groups, the condition does not significantly affect the outcomes, although there is a tendency to offer a higher risk of PICU admission among adolescents on the adjusted model (OR 1.28 95\%CI 0.98-1.67).

This analysis is one of the largest performed in Brazil to study the role of asthma in COVID-19 pediatric patients. We have found that for children aged 5 to 10 years, a previous diagnosis of asthma might be a protective factor for mortality, reducing the odds of death by $60 \%$. For adolescents, and for other outcomes like PICU admission and use of IVS, there seems to be no association between exposure and outcome.

Asthma is one of the most important risk factors for morbidity in respiratory infectious diseases. ${ }^{2}$ Therefore, it is odd to find the condition not associated with poor outcomes in COVID-19 patients. However, these results are not unique in the literature. In a metanalysis by Sunjaya et al., including more than 965,000 COVID-19 patients of all ages, asthma was not a risk factor for ICU admission, ventilator use, and mortality. ${ }^{3}$ Harwood et al. included 21,412 children in a metanalysis that found asthma to reduce the odds of admission to critical care and mortality. ${ }^{4}$ The study is published as a preprint, pending peer-review. Putting our results together with previous findings, it is coming clear that indeed asthma is not a risk factor for poor outcomes in COVID-19 children and adolescents, and might protect against some of them.

The main paths by which asthma and other allergic diseases might confer protection against COVID-19 morbidity and mortality are still up for discussion, but the role of the type of asthma phenotype is among the main hypotheses. Current knowledge classifies the pathogenesis of asthma into type 2 (T2) high and T2low, with a predominance of eosinophilic inflammation in the former, and a predominance of neutrophils in the latter. ${ }^{5}$ The predominance of T2-high allergic asthma among children is well known, reaching up to $80 \%$ 
of the cases and being more responsive to corticosteroids, while in adults with obesity and without allergic sensitization, T2-low asthma predominates with little action of corticosteroids. ${ }^{6}$ Recently the cytokines IL4 and IL-13, more expressed in T2-high phenotype, were demonstrated to reduce the expression of the angiotensin 2 receptor (ACE2) in the airway epithelial cells, the gateway for the SARS-COV-2 virus. On the other hand, the cytokines IL-12, IL-17, and TNF can increase the expression of ACE2 in T2-low asthmatics and in chronic obstructive pulmonary disease patients. ${ }^{7,8}$

Another finding that has intrigued researchers is the role of eosinophils in COVID-19 patients with an allergic T2-high profile. Previously recognized only in responses to helminths and allergic diseases, eosinophils are currently known to have effector functions, especially in the digestive tract and airways, releasing cytokines and mediators that promote immunoregulation and antiviral activity. ${ }^{9}$ Furthermore, many reports have shown the potential effects of eosinophils during the COVID-19 pandemic: absence of eosinophils on the first day of hospitalization in non-asthmatic patients is associated with worse prognosis ${ }^{10}$, patients with a low number of eosinophils require longer hospitalizations and an increase in eosinophils is associated with COVID-19 improvement and hospital discharge. ${ }^{11}$

The main limitations of this study are related to its reliance on secondary data. Case ascertainment bias is a possibility, as is underreporting. There is also a considerable rate of missingness for some characteristics, especially ethnicity. Notably, the asthma diagnosis is self or parent-reported, without objective parameters like spirometry or an in-depth clinical evaluation. This leads to a considerable degree of subjectivity, as a previous history of recurrent wheezing might be reported as asthma, for instance. This also justified the age group chosen for analysis, since before 5 years of age, wheezing episodes could be more related to viral conditions. On the other hand, a fair amount of underdiagnosis is expected, especially in regions with a higher socioeconomic vulnerability and lower health care access. It is also important to note that among all the comorbidities reported in the database, asthma is the only one that confers protection against mortality, with all of the others tending to confer risk, as previously showed by our group.

In conclusion, we have described the role of asthma on the outcomes of hospitalized children and adolescents with COVID-19 in Brazil. In this population, the disease is not a risk factor for PICU admission and use of IVS, and protects against mortality among children. Considering that asthma is one of the most common chronic diseases of childhood, these findings are important for public health measures concerning school reopening and vaccination.

Braian Lucas Aguiar Sousa, MD

University of São Paulo School of Medicine - Department of Pediatrics. Sao Paulo, Brazil.

Paulo Victor Ferreira Mai, MD

University of São Paulo School of Medicine - Department of Pediatrics. Sao Paulo, Brazil.

Sandra Elisabete Vieira, MD, PhD

University of São Paulo School of Medicine - Department of Pediatrics. Sao Paulo, Brazil.

Antonio Carlos Pastorino, MD, PhD

University of São Paulo School of Medicine - Department of Pediatrics. Sao Paulo, Brazil.

Alexandre Archanjo Ferraro, MD, PhD

University of São Paulo School of Medicine - Department of Pediatrics. Sao Paulo, Brazil.

\section{REFERENCES:}

1-Sousa BLA, Brentani A, Costa Ribeiro CC, et al. Non-communicable diseases, sociodemographic vulnerability and the risk of mortality in hospitalised children and adolescents with COVID-19 in Brazil: a cross-sectional observational study. BMJ Open. 2021;11(9):e050724. 
2- Juhn YJ. Risks for infection in patients with asthma (or other atopic conditions): is asthma more than a chronic airway disease?. J Allergy Clin Immunol. 2014;134(2):247-259.

3- Sunjaya AP, Allida SM, Di Tanna GL, Jenkins CR. Asthma and Coronavirus Disease 2019 Risk: a systematic review and meta-analysis [published online ahead of print, 2021 Aug 24]. Eur Respir J. 2021;2101209.

4- Harwood R, Yan H, Talawila Da Camara N, et al. Which children and young people are at higher risk of severe disease and death after SARS-CoV-2 infection: a systematic review and individual patient metaanalysis. MedRxiv 2021.06.30.21259763.

5- Coverstone AM, Seibold MA, Peters MC. Diagnosis and Management of T2-High Asthma. J Allergy Clin Immunol Pract. 2020;8(2):442-450.

6- Fitzpatrick AM, Chipps BE, Holguin F, Woodruff PG. T2-"Low" Asthma: Overview and Management Strategies. J Allergy Clin Immunol Pract. 2020;8(2):452-463.

7- Kimura H, Francisco D, Conway M, et al. Type 2 inflammation modulates ACE2 and TMPRSS2 in airway epithelial cells. J Allergy Clin Immunol. 2020;146(1):80-88.e8.

8- Song J, Zeng M, Wang H, et al. Distinct effects of asthma and COPD comorbidity on disease expression and outcome in patients with COVID-19. Allergy. 2021;76(2):483-496.

9- Lindsley AW, Schwartz JT, Rothenberg ME. Eosinophil responses during COVID-19 infections and coronavirus vaccination. J Allergy Clin Immunol. 2020;146(1):1-7.

10- Tanni F, Akker E, Zaman MM, Figueroa N, Tharian B, Hupart KH. Eosinopenia and COVID-19 [published online ahead of print, 2020 Jul 16]. J Am Osteopath Assoc. 2020;10.7556/jaoa.2020.091.

11- Xie G, Ding F, Han L, Yin D, Lu H, Zhang M. The role of peripheral blood eosinophil counts in COVID-19 patients. Allergy. 2021;76(2):471-482.

Keywords: COVID-19, asthma, pediatrics, children, SARS-CoV-2, epidemiology.

\begin{tabular}{|c|c|c|c|c|c|c|}
\hline & & $\begin{array}{l}\text { Asthmatic } \\
(\mathrm{N}=858)\end{array}$ & $\begin{array}{l}\text { Asthmatic } \\
(\mathrm{N}=858)\end{array}$ & $\begin{array}{l}\text { Non- } \\
\text { Asthmatic } \\
(\mathrm{N}=8,949)\end{array}$ & $\begin{array}{l}\text { Non- } \\
\text { Asthmatic } \\
(\mathrm{N}=8,949)\end{array}$ & \\
\hline Characteristic & Categories & $\mathbf{N}$ & $\%$ & $\mathbf{N}$ & $\%$ & p-value \\
\hline Region & North & 247 & 28.8 & 3,008 & 33.6 & 0.004 \\
\hline \multirow[t]{3}{*}{ Age } & 5-10yrs & 386 & 45 & 2,117 & 23.7 & - \\
\hline & $10-15 y r s$ & 213 & 24.8 & 2,071 & 23.1 & \\
\hline & $15-20 y r s$ & 259 & 30.2 & 4,761 & 53.2 & \\
\hline Sex & Male & 445 & 51.9 & 4,275 & 47.8 & 0.022 \\
\hline Ethnicity & Non-White & 388 & 54.6 & 4,202 & 57.2 & 0.195 \\
\hline NCDs & $\begin{array}{l}\text { With other } \\
\text { NCDs }\end{array}$ & 260 & 30.3 & 3,284 & 36.7 & $<0.001$ \\
\hline $\begin{array}{l}\text { PICU } \\
\text { Admission }\end{array}$ & Yes & 246 & 30.6 & 2,352 & 28.9 & 0.311 \\
\hline IVS & Yes & 99 & 12.6 & 990 & 12.7 & 0.904 \\
\hline Death & Yes & 55 & 6.4 & 898 & 10 & 0.001 \\
\hline
\end{tabular}

Table 1: Sociodemographic characteristics and clinical outcomes of asthmatic and non-asthmatic patients. Frequencies are number $(\mathrm{N})$ and percentages (\%). NCDs: noncommunicable diseases; PICU: pediatric intensive care unit; IVS: invasive ventilatory support. p: chi-square test. 


\begin{tabular}{|c|c|c|c|c|c|c|c|}
\hline & & $\begin{array}{l}\text { Crude } \\
\text { model }\end{array}$ & $\begin{array}{l}\text { Crude } \\
\text { model }\end{array}$ & $\begin{array}{l}\text { Crude } \\
\text { model }\end{array}$ & $\begin{array}{l}\text { Adjusted } \\
\text { model }\end{array}$ & $\begin{array}{l}\text { Adjusted } \\
\text { model }\end{array}$ & $\begin{array}{l}\text { Adjusted } \\
\text { model }\end{array}$ \\
\hline \multirow{3}{*}{$\begin{array}{l}\text { Outcomes } \\
\text { PICU } \\
5-10 \text { yo }\end{array}$} & Category & OR & $95 \% \mathrm{CI}$ & $\mathrm{p}$ & OR & $95 \% \mathrm{CI}$ & $\mathrm{p}$ \\
\hline & $\begin{array}{l}\text { Non- } \\
\text { Asthmatic }\end{array}$ & 1.00 & - & - & 1.00 & - & - \\
\hline & Asthmatic & 0.96 & $0.72-1.29$ & 0.81 & 1.09 & $0.79-1.51$ & 0.58 \\
\hline \multirow[t]{2}{*}{$\begin{array}{l}\text { PICU } \\
10-20 \text { yо }\end{array}$} & $\begin{array}{l}\text { Non- } \\
\text { Asthmatic }\end{array}$ & 1.00 & - & - & 1.00 & - & - \\
\hline & Asthmatic & 1.09 & $0.85-1.39$ & 0.49 & 1.28 & $0.98-1.67$ & 0.07 \\
\hline \multirow[t]{2}{*}{ IVS 5-10yo } & $\begin{array}{l}\text { Non- } \\
\text { Asthmatic }\end{array}$ & 1.00 & - & - & 1.00 & - & - \\
\hline & Asthmatic & 0.75 & $0.50-1.12$ & 0.17 & 0.88 & $0.56-1.39$ & 0.59 \\
\hline \multirow[t]{2}{*}{ IVS 10-20yo } & $\begin{array}{l}\text { Non- } \\
\text { Asthmatic }\end{array}$ & 1.00 & - & - & 1.00 & - & - \\
\hline & Asthmatic & 1.22 & $0.90-1.64$ & 0.20 & 1.31 & $0.95-1.81$ & 0.10 \\
\hline \multirow[t]{2}{*}{$\begin{array}{l}\text { Death } \\
5 \text {-10yo }\end{array}$} & $\begin{array}{l}\text { Non- } \\
\text { Asthmatic }\end{array}$ & 1.00 & - & - & 1.00 & - & - \\
\hline & Asthmatic & 0.43 & $0.21-0.88$ & 0.02 & 0.44 & $0.20-0.97$ & 0.04 \\
\hline \multirow[t]{2}{*}{$\begin{array}{l}\text { Death } \\
10-20 \text { yo }\end{array}$} & $\begin{array}{l}\text { Non- } \\
\text { Asthmatic }\end{array}$ & 1.00 & - & - & 1.00 & - & - \\
\hline & Asthmatic & 0.80 & $0.56-1.14$ & 0.22 & 0.89 & $0.60-1.32$ & 0.56 \\
\hline
\end{tabular}

Table 2: Comparison of risk for severe outcomes in asthmatic and non-asthmatic patients. Results of multilevel mixed-effects generalized linear models, with municipality and hospital as random effects Models adjusted for sex, age group, region, ethnicity and presence of other comorbidities. YO: years old. PICU: pediatric intensive care unit; IVS: invasive ventilatory support; OR: odds ratio; 95\% CI: 95\% confidence interval. 